\title{
Taxation and tobacco plain packaging effect on Saudi smokers quitting intentions in Riyadh city, Saudi Arabia
}

\author{
Sultan O. Aljuaid, MD, Sulaiman A. Alshammari, FRCGP, MFPH, Fatma A. Almarshad, BSc, Khalid S. Almutairi, MD, \\ Abdullah S. Aljumayi, MD, Hesham I. AlKhashan, MD, SBFM, Rizwan A. Suliankatchi, MD.
}

\begin{abstract}
الأهداف : دراسة تأثير زيادة ضريبة التبغ وتطبيق التغليف البسيط على نوايا

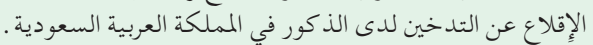

المنهجية : استخدمت هذه إلدراسة المنهج الكمي حيث منار وزعنا استبيانات

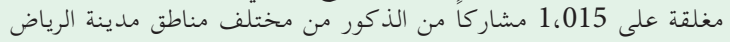

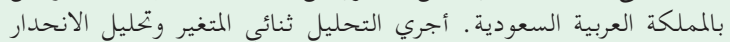

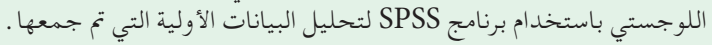

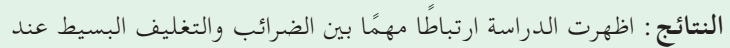

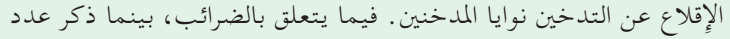

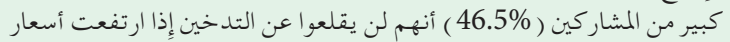

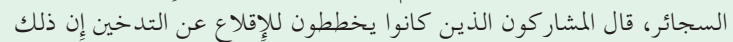

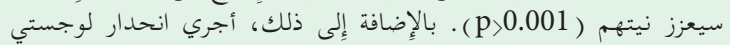

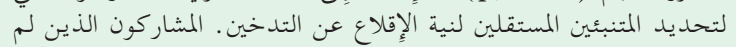

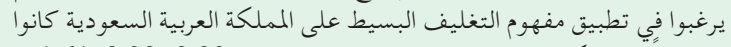

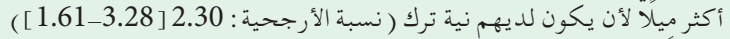

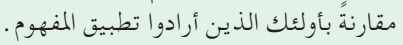

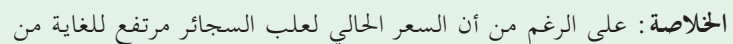

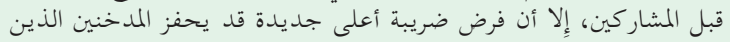

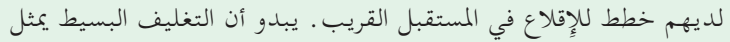

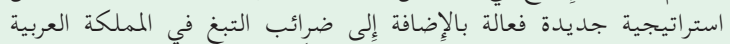

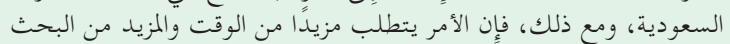
لتقييم فعالية الاستراتيجية.
\end{abstract}

Objectives: The current research aims to study the impact of raising tobacco tax and implementation of plain packaging on male smokers' quitting intentions in Saudi Arabia.

Methods: The study adopts a quantitative approach where close-ended questionnaires are distributed among 1,015 male participants from different regions of Riyadh city, Saudi Arabia. Bivariate analysis and logistic regression analysis are conducted using SPSS software to analyze the collected primary data.

Results: The study found a significant association of taxation and plain packaging on the quitting intentions of smokers. On taxation, while a considerable number of participants $(46.5 \%)$ stated that they would not quit smoking if the cigarette prices increased, participants who were planning to give up smoking said it would strengthen their intention $(p<0.001)$. In addition, logistic regression was performed to identify the independent predictors of quitting intention. Participants who did not want to apply the concept of plain packaging to Saudi Arabia were more likely to have quitting intention (odds ratio: 2.30 [1.61-3.28]) in comparison to those who wanted to apply the concept.

Conclusion: Although the current price of cigarette packs reported to be very high by the participants, imposing a new higher tax may motivate smokers who had plans to quit in the near future. Plain packaging seems to be an effective new strategy in addition to tobacco taxation in Saudi Arabia, yet, more time and further research are required to assess the effectiveness of the strategy.

Keywords: taxation, plain packaging, tobacco, cigarette smoking

Saudi Med J 2020; Vol. 41 (10): 1121-1129 doi: 10.15537/smj.2020.10.25390

From the Department of Family and Community Medicine (Aljuaid, Alshammari), College of Medicine, King Saud University; from the Assistant Agency for Primary Health Care (Almarshad), from the Department of Academic Affairs \& Training (Almutairi), Ministry of Health; from the Internal Medicine Department (Aljumayi), from the Medical Services (AlKhashan), Prince Sultan Military Medical City; and from the ICMR-National Institute of Epidemiology (Suliankatchi), Ayapakkam, Chennai, India.

Received 30th June 2020. Accepted 1st September 2020.

Address correspondence and reprint request to: Prof. Sulaiman A. Alshammari, Health Promotion and Health Education Research Chair, Department of Family and Community Medicine, College of Medicine, King Saud University Medical City, Riyadh, Kingdom of Saudi Arabia. E-mail: amsahsa@gmail.com

ORCID ID: https://orcid.org/0000-0001-9596-5590 
G lobally, tobacco use is the leading cause of I preventable death with heavy economic impact on countries each year as costs of smoking-related illnesses in terms of direct medical care and lost productivity. ${ }^{1}$ An estimated, 6 million people are killed each year as a result of direct tobacco use and second-hand smoke exposure. ${ }^{2}$ Tobacco kills one person every 6 seconds. If no serious actions has been taken, the number of deaths will rise to 8 million people per year by $2030 .^{3}$ Smoking is a significant preventable public health problem in Saudi Arabia. Though the Kingdom of Saudi Arabia has a population of around 33 million, it ranks fourth in terms of global tobacco imports. ${ }^{4}$ Roughly, $14.9 \%$ of Saudi Arabian youth and $12 \%$ of adults are tobacco users. Furthermore, the prevalence of smoking among men was $23.7 \%$, while prevalence in females was much lower $1.5 \%$ as reported by WHO report on the global tobacco epidemic. ${ }^{5}$ Recent report on the global tobacco epidemic by the $\mathrm{WHO}$, labeled raising taxes on tobacco as the most effective way to reduce its use. ${ }^{1}$ Increasing the price of popular tobacco packs from $\$ 2.67$ to $\$ 8.27$ may lead to smoking cessation in Saudi Arabia. ${ }^{6}$ Different anti-smoking measures reinforcement in Saudi Arabia by enactment of anti-smoking laws and collaboration with governmental ministries. ${ }^{7}$ Plain packaging appears to be promising effective method if implemented in conjunction with other tobacco control polices to reduce the appeal of smoking and packets. $^{8}$ In 2012, Australia was the first of the WHO member countries to implement the plain packaging law. Since then, different member states of WHO, including France, Ireland, and the UK have passed similar laws. ${ }^{9}$ The effect of plain packaging extended to outdoor settings such as cafés, restaurants and bars led to behavioral change with a reduction in clearly visible packs on tables. ${ }^{10}$ However, such measures have given rise to several concerns with many countries, including the USA and Canada, facing legal difficulties as tobacco companies file lawsuits against the placement of warnings and graphic images of tobacco-related diseases on cigarette packages. ${ }^{11}$

In the light of such challenges, it is essential to first understand the impact of these strategies on the intentions of consumers towards their smoking behavior. Thus, the current study aims to assess the influence of tobacco taxation and implementation of plain

Disclosure. Authors have no conflict of interests, and the work was not supported or funded by any drug company. packaging on the motivations of Saudi male smokers to quit smoking. This will enable policy makers to consider and maintain the application of higher taxes on tobacco and plain packages as tobacco control measures that will con-tribute to other ongoing measures for reducing the prevalence of tobacco smoking in the Kingdom.

Methods. We conducted a cross-sectional study using a quantitative research approach in Riyadh, Saudi Arabia, from 2018 to 2020 . The study was carried out among cigarette smokers in 15 coffee shops that permit either indoor or outdoor smoking in the northern, southern, eastern, western, and central regions of Riyadh.

The target population for our survey only included males who were at 15 selected coffee shops from northern, southern, eastern, western, and central regions of Riyadh.

Inclusion criteria were: Saudi adult males aged 18 years and above and Saudi adult males who are cigarettes smokers. Exclusion criteria were E-cigarettes smokers and those who smoke other types of products such as shisha or water pipe; and former smokers.

A non-probability quota sampling method was adopted, where Riyadh city was divided into 5 geographical locations (northern, southern, eastern, western, and central regions). Fifteen coffee shops, 3 from each region, were selected based on the nearest availability of the Global Positioning System (GPS) to represent all 5 geographical locations of Riyadh city.

The study sample size was estimated according to the following formula:

$$
\mathrm{n}=(\mathrm{z})^{2} p(1-p) / \mathrm{d}^{2}
$$

Where, $\mathrm{n}=$ sample size, $\mathrm{Z}=1.96$ at $95 \%$ level of significance, $p=$ estimated prevalence of Saudi smokers with successful quitting attempts $(25.3 \%),{ }^{12} \mathrm{~d}=$ margin of error (0.05).

In our study, the calculated $\mathrm{n}$ was approximately 290. Based on the above formula and after adjustment for the design effect of 3 and $85 \%$ expected response rate, 1,015 participants were invited conveniently to participate in the study while they were at coffee shops. We showed to the participants the IRB approval, and after discussing the study all of them signed the informed consent.

Primary data for this study were collected using an online questionnaire; it was self-administered on iPad devices by cigarette smokers at the selected coffee shops. The questionnaire used was a validated tool that was used in a previously published study, following 
permission from the principal investigator. ${ }^{6}$ The adopted questionnaire was modified and translated from English into Arabic by the principal investigator according to the WHO guidelines. Some of the questions were also taken from Global Adult Tobacco Survey (GATS), modified cut-annoyed-guilty-eye (CAGE) questionnaire for smoking and Brief Fagerström Test for Nicotine Dependence which are validated tools to screen for nicotine dependence and to assess the intensity of dependence respectively. ${ }^{13,14}$

The questionnaire employed in this study was divided into 3 sections that included demographic data, smoking history, and quit smoking intentions. Pictures demonstrating the concept of plain packaging were shown to participants using iPads when necessary. Permission to use plain packaging images from the Tobacco Control Section, Department of Health, Australian Government, had been obtained. Deed of licence was signed for the release of 10 images with full resolution for use in the study.

In the current study, prior to conducting the fullfledged research and data collection, the questionnaire was piloted among 20 participants to test its feasibility.

Study variables. The variables considered in the questionnaire are taxation on tobacco products, tobacco plain packaging, reasons to quit smoking, attempts to quit smoking, duration of quitting attempts age, marital status, education level and level of income, which is considered as the independent variables while intentions to quit smoking was our primary dependent variable in this study.

Data management and analysis. Data were analyzed using IBM SPSS Statistics for Mac, version 20 (IBM Corp., Armonk, N.Y., USA). Bivariate analysis was conducted, and the $p$-value was used to show the probability of the results. Logistic regression was used for some of the questions to predict the response of quitting intention to the plain packaging application. Data quality is ensured throughout the processes of data cleaning, ordering, and coding, and the identification of confounding variables that may lead to invalid conclusions.

Ethical consideration. Ethics, in any part of human life, determines the values of an individual. In research, it is imperative to follow such ethics that ensures that the study conducted is not based on any untrue or unjust approach that may hurt readers' beliefs. Approval to conduct the research was granted by the Institutional Review Board Committee of the Ministry of Health. Approval for the project was also obtained from the Ethical Committee. Permission to collect data from participants was obtained from the café managers before approaching the participants. Informed consent was signed by the respondents following an explanation of the objectives of the research and utilization of the results. The information about identity has not been stored and the collected information is fully protected with consideration of the participant's rights and safety. Subjects will not be contacted for follow-up information.

Results. Considering the demographic data collected via the questionnaire, it is inferred from the statistical analysis that the average age of the participants was 28 years old, as demonstrated in Table 1. A majority of participants who intended to quit within the next 6 months had incomes less than or equal to SAR3,000 (25.3\%) and between SAR7,001-12,000 (26.2\%). A majority of the participants $(58.1 \%)$ were graduates, and $68 \%$ of the respondents were single, never married. Demographic data falls in 2 categories. From a total of 960 participants with $94 \%$ response rate, 308 were planning to quit smoking in the next 1-6 months, while 652 of the participants denied any such intention. As per bivariate analysis, when determining the relationship between the demographic factors and intentions of the population to quit smoking, it was found that there was no association between age and intention to quit, with a $p$-value of $>0.05$. No significant association was found between other variables, including income, education level, marital status, and intention to quit.

As per the statistical analysis, most of the respondents were indulging in smoking for more than 8 years, and most of them started smoking after 18 years of age, as shown in Table 2. It is evident from the analysis that most of the population started smoking from an early age. A majority of the participants (50.2\%) started smoking 31-60 minutes after waking up in the morning. Furthermore, $68.5 \%$ of the participants smoked 11 to 20 cigarettes in a day, $19.8 \%$ had an intake of 20 to 30 cigarettes, and $11.7 \%$ had more than 30 cigarettes per day. These statistics correspond to levels of addiction to tobacco or smoking among the populace.

The Chi-square test revealed that there is a significant association between the number of cigarettes consumed in a day and the intention to quit smoking was $p<0.001$. In addition, there was a significant association between the duration of time in the morning when the participants indulged in smoking and their intention to quit, with a $p$-value less than 0.003 .

A majority of the participants $67.9 \%$ stated that they had no intention to quit smoking. Among the participants who wanted to quit, $39.5 \%$ stated that they want to quit smoking due to health issues. A minority 
Taxation and tobacco plain packaging ... Aljuaid et al

Table 1 - Distribution of demographic characteristics of the study participants by their intention to quit smoking in Riyadh city.

\begin{tabular}{|c|c|c|c|c|}
\hline Characteristics & $\begin{array}{c}\text { Total } \\
\mathrm{n}=960(\%)\end{array}$ & $\begin{array}{l}\text { Planning to quit in } \\
\text { next } 1 \text { month or } 6 \\
\text { months } n=308(\%)\end{array}$ & $\begin{array}{l}\text { Not planning to } \\
\text { quit or plan to cut } \\
\text { back } n=652(\%)\end{array}$ & $P$-value \\
\hline Age $($ mean $\pm S D)$ & $28.1 \pm 7.5$ & $28.2 \pm 7.8$ & $28.1 \pm 7.4$ & 0.87 \\
\hline $\begin{array}{l}\text { Income } \\
\quad \leq 3000 \\
\quad 3001-7000 \\
7001-12000 \\
12001-18000 \\
18001-25000\end{array}$ & $\begin{array}{r}249(25.9) \\
215(22.4) \\
248(25.8) \\
201(20.9) \\
47 \quad(4.9)\end{array}$ & $\begin{array}{l}78(25.3) \\
61(19.8) \\
81(26.3) \\
74(24.0) \\
14 \quad(4.5)\end{array}$ & $\begin{array}{l}171(26.2) \\
154(23.6) \\
167(25.6) \\
127(19.5) \\
33(5.1)\end{array}$ & 0.46 \\
\hline $\begin{array}{l}\text { Education } \\
\text { Uneducated } \\
\text { Intermediate school } \\
\text { Secondary school } \\
\text { University degree } \\
\text { Postgraduate degree } \\
\text { (Master's, Doctorate) }\end{array}$ & $\begin{array}{rr}2 & (0.2) \\
3 & (0.3) \\
310 & (32.3) \\
558 & (58.1) \\
87 & (9.1)\end{array}$ & $\begin{array}{rr}0 & (0.0) \\
2 & (0.6) \\
97 & (31.5) \\
187 & (60.7) \\
22 & (7.1)\end{array}$ & $\begin{array}{rr}2 & (0.3) \\
1 & (0.2) \\
213 & (32.7) \\
371 & (56.9) \\
65 & (10.0)\end{array}$ & $0.28^{\#}$ \\
\hline $\begin{array}{l}\text { Marital status } \\
\text { Single, never married } \\
\text { Currently married } \\
\text { Widowed } \\
\text { Divorced }\end{array}$ & $\begin{array}{r}654(68.1) \\
293(30.5) \\
2 \quad(0.2) \\
11 \quad(1.1)\end{array}$ & $\begin{array}{rr}211 & (68.5) \\
95 & (30.8) \\
0 & (0.0) \\
2 & (0.6)\end{array}$ & $\begin{array}{rr}443 & (67.9) \\
198 & (30.4) \\
2 & (0.3) \\
9 & (1.4)\end{array}$ & $0.58^{\#}$ \\
\hline $\begin{array}{l}\text { Children }^{a} \\
\text { Yes } \\
\text { No }\end{array}$ & $\begin{array}{l}237(54.2) \\
200(45.8)\end{array}$ & $\begin{array}{l}77(52.4) \\
70(47.6)\end{array}$ & $\begin{array}{l}160(55.2) \\
130(44.8)\end{array}$ & 0.58 \\
\hline
\end{tabular}

Table 2 - Distribution of smoking characteristics of the study participants by their intention to quit smoking in Riyadh city.

\begin{tabular}{|c|c|c|c|c|}
\hline Characteristics & $\begin{array}{c}\text { Total } \\
(n=960)\end{array}$ & $\begin{array}{l}\text { Planning to quit } \\
\text { in next } 1 \text { month } \\
\text { or } 6 \text { months } \\
\quad(n=308)\end{array}$ & $\begin{array}{l}\text { Not planning to } \\
\text { quit or plan to } \\
\text { cut back } \\
(n=652)\end{array}$ & $P$-value \\
\hline Duration of smoking (years) $($ mean $\pm S D)$ & $8.7(6.4)$ & $8.5(6.3)$ & $8.8(6.4)$ & 0.49 \\
\hline Age of initiation (years) $($ mean $\pm S D)$ & $18.8(3.7)$ & $19.1(3.9)$ & $18.7(3.7)$ & 0.10 \\
\hline How soon after waking up? & & & & 0.003 \\
\hline$<5$ minutes & $196(20.4)$ & $52(16.9)$ & $144(22.1)$ & \\
\hline $5-30$ minutes & $282(29.4)$ & $77(25.0)$ & $205(31.4)$ & \\
\hline $31-60$ minutes & $482(50.2)$ & $179(58.1)$ & $303(46.5)$ & \\
\hline No. of cigarettes & & & & $<0.001$ \\
\hline 11 to 20 & $658(68.5)$ & $243(78.9)$ & $415(63.7)$ & \\
\hline 21 to 30 & $190(19.8)$ & $44(14.3)$ & $146(22.4)$ & \\
\hline$>30$ & $112(11.7)$ & $21(6.8)$ & $91(14.0)$ & \\
\hline Mean no. of cigarettes (SD) & $20.6(10.0)$ & $18.4(8.9)$ & $21.6(10.3)$ & $<0.001$ \\
\hline
\end{tabular}


of $10.5 \%$ of the people wanted to quit for social reasons (Table 3).

As shown in Table 4, 49.7\% of the participants had not tried to stop smoking, while $47 \%$ of the participants had initiated measures to reduce smoking in the past 12 months. Among the participants who intended to quit smoking, $66.6 \%$ had tried to stop smoking in the past 12 months. With a $p$-value less than 0.001 , this

Table 3 - Distribution of the study participants by their intention to quit smoking in Riyadh city.

\begin{tabular}{lr}
\hline Questions/statements & $\mathbf{n}(\%)$ \\
\hline Plan to quit smoking & \\
I am planning to quit in the next month & $123(12.8)$ \\
Am planning to quit in the next 6 months & $185(19.3)$ \\
I would like to cut back & $313(32.6)$ \\
I am not planning to quit & $339(35.3)$ \\
Intention to quit smoking & \\
Yes & $308(32.1)$ \\
No & $652(67.9)$ \\
Reasons for planning to quit & \\
Religious reasons & $31(3.2)$ \\
Social reasons & $101(10.5)$ \\
Economic reasons & $55(5.7)$ \\
Health reasons & $379(39.5)$ \\
Others & $55(5.7)$ \\
\hline
\end{tabular}

factor, where participants have tried quitting in the past 12 months, has a significant association with their intention to quit. Out of 21 variables, there were 12 variables that were significantly associated with quitting intentions $(p<0.05)$, while the other 9 variables had a non-significant association with quitting intentions $(p>0.05)$.

When the participants were asked about the present price of cigarette packets, $43.6 \%$ of the participants stated that it was very expensive. However, price has no significant association with the intention to quit smoking, with a $p$-value greater than 0.05. Many of the participants (46.5\%) stated that they had no intention to quit smoking if the cigarette prices increased. However, participants who were planning to quit, stated that higher prices of cigarettes, would motivate them to quit with $p<0.001$, it was observed that increasing the prices has a significant association with intentions to quit.

When considering the impact of health warnings on current cigarette packs, as per the Chi-square test, it was established that reading health warnings and the clarity of such messages has a significant association with the intention to quit. Further, $48.3 \%$ of the participants stated their desire to apply the concept of plain packaging in Saudi Arabia. A significant

Table 4 - Determinants of intention to quit smoking among the study participants in Riyadh city (Bivariate analysis).

\begin{tabular}{|c|c|c|c|c|}
\hline Determinants of intention & $\begin{array}{r}\text { Total } \\
(\mathbf{n}=960)\end{array}$ & $\begin{array}{l}\text { Planning to quit in } \\
\text { next } 1 \text { month or } 6 \\
\text { months }(n=308)\end{array}$ & $\begin{array}{l}\text { Not planning to quit } \\
\text { or plan to cut back } \\
(n=652)\end{array}$ & $P$-value \\
\hline During past 12 months, have you tried to stop smoking? & & & & $<0.001$ \\
\hline Yes & $451(47.0)$ & $205(66.6)$ & $246(37.7)$ & \\
\hline No & $477(49.7)$ & $91(29.5)$ & $386(59.2)$ & \\
\hline Don't know & $32 \quad(3.3)$ & $12(3.9)$ & $20(3.1)$ & \\
\hline Most recent attempt & & & & 0.37 \\
\hline Last week & $21 \quad(4.7)$ & 10 & $11(4.5)$ & \\
\hline More than one week but less than a month & $70 \quad(15.5)$ & $35(17.1)$ & $35(14.2)$ & \\
\hline $\begin{array}{l}\text { More than one month but less than six } \\
\text { months }\end{array}$ & $157(34.8)$ & $77(37.6)$ & $80(32.5)$ & \\
\hline More than 6 months & $203(45.0)$ & $83(40.5)$ & $120(48.8)$ & \\
\hline $\begin{array}{l}\text { Longest duration of quitting attempt in days } \\
(\text { mean } \pm S D)\end{array}$ & $54.0 \pm 128.6$ & $67.5 \pm 166.9$ & $47.6 \pm 105.3$ & $<0.001^{\#}$ \\
\hline Feeling of cut-down or to control smoking & & & & $<0.001$ \\
\hline Yes & 639 (66.6) & $238(77.3)$ & $401(61.5)$ & \\
\hline No & $238 \quad(24.8)$ & $56(18.2)$ & $182(27.9)$ & \\
\hline Don't know & $83 \quad(8.6)$ & $14(4.5)$ & $69(10.6)$ & \\
\hline $\begin{array}{l}\text { Felt annoyed or angry with people who criticize your } \\
\text { smoking }\end{array}$ & & & & 0.005 \\
\hline Yes & $357 \quad(37.2)$ & $106(34.4)$ & $251(38.5)$ & \\
\hline No & $546 \quad(56.9)$ & $193(62.7)$ & $353(54.1)$ & \\
\hline Don't know & $\begin{array}{ll}57 & (5.9)\end{array}$ & $9 \quad(2.9)$ & $48 \quad(7.4)$ & \\
\hline
\end{tabular}


Taxation and tobacco plain packaging ... Aljuaid et al

Table 4 - Determinants of intention to quit smoking among the study participants in Riyadh city (Bivariate analysis) (continued).

\begin{tabular}{|c|c|c|c|c|}
\hline Felt guilty about your smoking & & & & $<0.001$ \\
\hline Yes & $415(43.2)$ & $191(62.0)$ & $224(34.4)$ & \\
\hline No & $459(47.8)$ & $90(29.2)$ & $369(56.6)$ & \\
\hline Don’t know & $86(9.0)$ & $27(8.8)$ & $59(9.0)$ & \\
\hline $\begin{array}{l}\text { Ever smoked within half an hour of waking-up (Eye- } \\
\text { opener) }\end{array}$ & & & & 0.008 \\
\hline Yes & $551(57.4)$ & $155(50.3)$ & $396(60.7)$ & \\
\hline No & $367(38.2)$ & $139(45.1)$ & $228(35.0)$ & \\
\hline Don’t know & $42(4.4)$ & $14(4.5)$ & $28(4.3)$ & \\
\hline Price of pack of cigarette & & & $4(0.6)$ & $0.46^{*}$ \\
\hline Very cheap & $5(0.5)$ & $1(0.3)$ & $7(1.1)$ & \\
\hline Cheap & $14(1.5)$ & $7 \quad(2.3)$ & $124(19.0)$ & \\
\hline Average & 175 (18.2) & $51(16.6)$ & $230(35.3)$ & \\
\hline Expensive & 347 (36.1) & $117(38.0)$ & $287(44.0)$ & \\
\hline Very expensive & 419 (43.6) & $132(42.9)$ & & \\
\hline $\begin{array}{l}\text { Increasing the pack price will affect your intention to } \\
\text { quit }\end{array}$ & & & & $<0.001$ \\
\hline Yes & $391(40.7)$ & $155(50.3)$ & $236(36.2)$ & \\
\hline No & $446(46.5)$ & $120(39.0)$ & $326(50.0)$ & \\
\hline Don’t know & $123(12.8)$ & $33(10.7)$ & $90(13.8)$ & \\
\hline $\begin{array}{l}\text { Ever read/noticed health warnings on current cigarette } \\
\text { packets }\end{array}$ & & & & 0.004 \\
\hline Yes & $777(80.9)$ & $268(87.0)$ & $509(78.1)$ & \\
\hline No & $163(17.0)$ & $36(11.7)$ & $127(19.5)$ & \\
\hline Don’t know & $20(2.1)$ & $4(1.3)$ & $16(2.5)$ & \\
\hline $\begin{array}{l}\text { Health warnings on current cigarette packet was clear } \\
\text { and understandable }\end{array}$ & & & & 0.006 \\
\hline Yes & $710(76.4)$ & 245 (80.9) & $465(74.3)$ & \\
\hline No & $98(10.5)$ & $34(11.2)$ & $64(10.2)$ & \\
\hline Don't know & $121(13.0)$ & $24(7.9)$ & $97(15.5)$ & \\
\hline $\begin{array}{l}\text { In last } 30 \text { days, have warning labels led you to think } \\
\text { about quitting your smoking? }\end{array}$ & & & & $<0.001$ \\
\hline Yes & $191(19.9)$ & $92(29.9)$ & $99(15.2)$ & \\
\hline No & $712(74.2)$ & $198(64.3)$ & $514(78.8)$ & \\
\hline Don't know & $57 \quad(5.9)$ & $18 \quad(5.8)$ & $39(6.0)$ & \\
\hline $\begin{array}{l}\text { In last } 30 \text { days, have you noticed any advertisements or } \\
\text { signs promoting cigarettes in stored where cigarettes are } \\
\text { sold? }\end{array}$ & & & & 0.06 \\
\hline Yes & $186(20.9)$ & $71(24.7)$ & $115(19.1)$ & \\
\hline No & $703(79.1)$ & $217(75.3)$ & $486(80.9)$ & \\
\hline Ever heard about the plain packaging & & & & 0.96 \\
\hline Yes & $400(41.7)$ & $128(41.6)$ & $272(41.7)$ & \\
\hline No & $560(58.3)$ & $180(58.4)$ & $380(58.3)$ & \\
\hline $\begin{array}{l}\text { After explaining the concept, do you think understood } \\
\text { the concept of plain packaging fully? }\end{array}$ & & & & 0.67 \\
\hline Yes & $635(82.5)$ & $201(80.7)$ & $434(83.3)$ & \\
\hline No & 77 (10.0) & $27(10.8)$ & $50 \quad(9.6)$ & \\
\hline Don't know & $58 \quad(7.5)$ & $21 \quad(8.4)$ & $37 \quad(7.1)$ & \\
\hline $\begin{array}{l}\text { Will you be able to differentiate the new plain packet } \\
\text { from the old one? }\end{array}$ & & & & 0.87 \\
\hline Yes & 699 (72.8) & $225(73.1)$ & $474(72.7)$ & \\
\hline No & $157(16.4)$ & $48(15.6)$ & $109(16.7)$ & \\
\hline Don't know & $104(10.8)$ & $35(11.4)$ & $69(10.6)$ & \\
\hline
\end{tabular}


Table 4 - Determinants of intention to quit smoking among the study participants in Riyadh city (Bivariate analysis) (continued).

\begin{tabular}{|c|c|c|c|c|}
\hline \multirow{2}{*}{\multicolumn{4}{|c|}{$\begin{array}{l}\text { Do you wish to apply the concept of plain packaging in } \\
\text { Saudi Arabia? }\end{array}$}} & $<0.001$ \\
\hline & & & & \\
\hline Yes & $464(48.3)$ & $187(60.7)$ & $277(42.5)$ & \\
\hline No & $363(37.8)$ & $72(23.4)$ & $291(44.6)$ & \\
\hline Don't know & $133(13.9)$ & $49(15.9)$ & $84(12.9)$ & \\
\hline \multirow{2}{*}{\multicolumn{4}{|c|}{$\begin{array}{l}\text { Do you think the concept of plain packaging will help } \\
\text { you in quitting? }\end{array}$}} & $<0.001$ \\
\hline & & & & \\
\hline Yes & $294(30.6)$ & $135(43.8)$ & $159(24.4)$ & \\
\hline No & $452(47.1)$ & $108(35.1)$ & $344(52.8)$ & \\
\hline Don't know & $214(22.3)$ & $65(21.1)$ & $149(22.9)$ & \\
\hline \multicolumn{4}{|l|}{ Do you find the new plain packaging more attractive? } & 0.10 \\
\hline Yes & $147(15.3)$ & $49(15.9)$ & $98(15.0)$ & \\
\hline No & $702(73.1)$ & $214(69.5)$ & $488(74.8)$ & \\
\hline Don't know & $111(11.6)$ & $45(14.6)$ & $66(10.1)$ & \\
\hline \multicolumn{4}{|l|}{ Which picture has more effect on your quitting } & 0.82 \\
\hline intentions? & $109(11.4)$ & $34(11.0)$ & $75(11.5)$ & \\
\hline Blindness & $487(50.7)$ & $156(50.6)$ & $331(50.8)$ & \\
\hline Peripheral vascular disease & $142(14.8)$ & $50(16.2)$ & $92(14.1)$ & \\
\hline Emphysema & $155(16.1)$ & $50(16.2)$ & $105(16.1)$ & \\
\hline Throat cancer & $67(7.0)$ & $18(5.8)$ & $49(7.5)$ & \\
\hline \multicolumn{5}{|l|}{ Increase risk of stroke } \\
\hline Do you suffer from any chronic disease? & & & & 0.65 \\
\hline Yes & $120(12.5)$ & $42(13.6)$ & $78(12.0)$ & \\
\hline No & $801(83.4)$ & $252(81.8)$ & $549(84.2)$ & \\
\hline Don't know & $39(4.1)$ & $14(4.5)$ & $25 \quad(3.8)$ & \\
\hline
\end{tabular}

Table 5 - Cut-Annoyed-Guilty-Eye (CAGE) questionnaire and Fagerström grading among the participants.

\begin{tabular}{|c|c|c|c|c|}
\hline Questionnaire and grading & $\begin{array}{c}\text { Total } \\
(\mathbf{n}=960)\end{array}$ & $\begin{array}{l}\text { Planning to quit in } \\
\text { next } 1 \text { month or } 6 \\
\text { months }(\mathrm{n}=308)\end{array}$ & $\begin{array}{l}\text { Not planning to } \\
\text { quit or plan to cut } \\
\text { back }(n=652)\end{array}$ & $P$-value \\
\hline $\begin{array}{l}\text { CAGE questionnaire } \\
\text { Screened positive } \\
\text { Screened negative }\end{array}$ & $\begin{array}{r}907(94.5) \\
53 \quad(5.5)\end{array}$ & $\begin{array}{r}297(96.4) \\
11 \quad(3.6)\end{array}$ & $\begin{array}{r}610(93.6) \\
42 \quad(6.4)\end{array}$ & 0.07 \\
\hline $\begin{array}{l}\text { Fagerström grading } \\
\text { Heavy nicotine dependence } \\
\text { Moderate nicotine dependence } \\
\text { Light nicotine dependence }\end{array}$ & $\begin{array}{l}127(13.2) \\
462(48.1) \\
371(38.6)\end{array}$ & $\begin{array}{r}22(7.1) \\
134(43.5) \\
152(49.4)\end{array}$ & $\begin{array}{l}105(16.1) \\
328(50.3) \\
219(33.6)\end{array}$ & $<0.001$ \\
\hline
\end{tabular}

association between the concept of plain packaging and the intention to quit smoking was established with $30.6 \%$ of participants thinking that it will help them to quit smoking. When asked about the impact of graphical images on the quitting intentions, a majority of the participants $(50.7 \%)$ stated that pictures related to peripheral vascular disease had a greater impact on them.

As per the CAGE questionnaire and Fagerstrom grading analysis (Table 5), it was revealed that a majority of the participants with light nicotine dependency had a higher desire to quit smoking. However, no association was found between positive screening from the CAGE questionnaire and the intention to quit. To assess the possible effect of variables on quitting intention, logistic regression was performed to identify independent predictors. Variables with a $p$-value $<0.25$ in the bivariate analysis were entered in the model for logistic regression. The proportion of participants who intended to quit was higher among those who had not tried to quit smoking in the last 12 months (OR: 3.18 [2.32 - 4.79]) compared to those who had tried 
quitting. Participants who did not want to apply the concept of plain packaging to Saudi Arabia had higher odds of quitting intention (OR: 2.30 [1.61 - 3.28]) in comparison to those who wanted to apply the concept. Moderate (OR: 0.39 [0.22 - 0.68]) nicotine-dependent individuals had lower odds of quitting intention as compared to those who had light nicotine dependence. Similarly, those who had not thought about quitting smoking after looking at the warning label on packages in the last 30 days had higher odds of quitting intention (OR: $1.86[1.28-2.70]$ ) than those who had thought about quitting smoking. Individuals who did not find plain packaging attractive (OR: 0.55 [0.35 - 0.87]) and those who did not know whether they had found the plain packaging more attractive (OR: 0.44 [0.24 $0.80]$ ) had lesser odds of quitting intention as compared to those who found the plain packaging more attractive (Table 6).

Discussion. It is inferred from the study that most of the participants consumed 11-20 cigarettes per day and had no intention to quit smoking. It was also found that most of the participants started smoking from the age of 18 years. Alqarni ${ }^{15}$ also had determined that most people acquire the habit of smoking during adolescence. As per the current analysis, there is a significant association between the number of cigarettes consumed in a day and the intention to quit smoking. In addition, there was a significant association between the duration of time in the morning after waking up when the participants started smoking and their intention to quit. The results of the current study also revealed that the current prices of cigarettes, though high, do not affect the consumption levels of people; however, higher prices would motivate people to quit smoking, thereby revealing that tobacco taxation has a positive impact on the smoking behavior of the people. This result aligns with a study conducted by Callison \& Kaestner, ${ }^{16}$ which found that increases in cigarette taxes lead to small decreases in cigarette consumption; however, sizeable tax increases, on the order of $100 \%$, will reduce smoking by $5 \%$. The results of the current study are also in line with those of a survey conducted by Campaign for Tobacco Free Kids, ${ }^{17}$ which found that raising tobacco taxes generates revenue and discourages people from smoking.

As per the analysis, no association was observed between the demographic factors (age, income, education, marital status, children) and intention to quit smoking. When considering the impact of health warnings on current cigarette packs, it was established that reading health warnings and the clarity of such messages has a significant association with consumers' intention to quit smoking. Further, a majority of the people wanted to apply the concept of plain packaging in Saudi Arabia. A significant association between the concept of plain packaging and the intention to quit smoking was established. Hassounah et $\mathrm{al}^{18}$ also found that smokers' response to the implementation of plain packaging in Saudi Arabia was strong and loud on both social and traditional media channels. The evidence confirms that plain packaging has an impact on perceived taste and quality. Different warning texts can be used for smoking-related health risks with lung diseases and cancer being the strongest motivational quitting message. ${ }^{19}$ In our study the majority of the participants reported pictorial image of peripheral vascular diseases as it may affect their intentions to quit.

Table 6 - Binary backward stepwise logistic regression analysis - determinants of intention to quit smoking among the study participants in Riyadh city.

\begin{tabular}{|c|c|c|}
\hline Variables & $\begin{array}{l}\text { Adjusted OR } \\
\text { (95\% CI) }\end{array}$ & $P$-value \\
\hline During past 12 months, have not tried to quit smoking & $3.18(2.32-4.79)$ & $<0.001$ \\
\hline In the last 30 days, warning labels on cigarette packages have not led to think about quitting & $1.86(1.28-2.70)$ & 0.001 \\
\hline Do not wish to apply the concept of plain packaging to Saudi Arabia & $2.30(1.61-3.28)$ & $<0.001$ \\
\hline Do not know whether they found the plain packaging more attractive & $0.44(0.24-0.80)$ & 0.007 \\
\hline Did not find the plain packaging more attractive & $0.55(0.35-0.87)$ & 0.01 \\
\hline Moderate nicotine dependence & $0.39(0.22-0.68)$ & 0.001 \\
\hline Heavy nicotine dependence & $0.65(0.37-1.11)$ & 0.12 \\
\hline
\end{tabular}


Wakefield, Hayes, Durkin, and Borland ${ }^{20}$ observed that plain pack smokers perceived their cigarettes as inferior in quality, giving less satisfaction than branded packs, and were more likely to have thoughts about quitting smoking at least once a week. They also found that plain pack smokers support the policy more than branded smokers. It is concluded that those smoking from plain packs perceived their cigarettes to be of inferior quality, which further affected their intentions to quit smoking.

Study limitations. We acknowledge several limitations to our study as the idea of plain packaging was applied in Saudi Arabia in the middle of the data collection phase, which may affect the level of awareness about the concept. Furthermore, we utilized plain packaging images, which may or may not have an impact on smokers' quitting intentions when compared to the actual plain cigarette packs.

In conclusion, the present study, based on Saudi Arabia, has revealed that most people start smoking cigarettes at the early age of 18 years. Although the current price of cigarette packs reported to be very high by the participants, imposing a new higher tax may motivate smokers who had plans to quit in the near future. Plain packaging seems to be an effective new strategy in addition to tobacco taxation in Saudi Arabia, yet, more time and further research are required to assess the effectiveness of the strategy.

Acknowledgment. We would like to thank Tobacco Control Section at the Australian Government Department of Health, especially John Mohoric, for their support and collaboration. We also extend our appreciation to Ms. Noura Alkhaldi for her participation in the translation process of the questionnaire. We would like to thank Editage (www.editage.com) for English language editing.

\section{References}

1. World Health Organization. WHO report on the global tobacco epidemic 2015: raising taxes on tobacco. Geneva (SW): World Health Organization. [cited 2015]. Available from: https://www.who.int/tobacco/global_report/2015/en/

2. World Health Organization. Tobacco Fact sheet. Geneva (SW): World Health Organization. [cited 2020]. Available from: https://www.who.int/news-room/fact-sheets/detail/tobacco

3. World Health Organization. The global tobacco crisis 2008, World Health Organization. [cited 2008]. Available at: https:// www.who.int/tobacco/mpower/mpower_report_tobacco_ crisis_2008.pdf

4. AlMoamary MS. Tobacco consumption: Is still a dilemma? Ann Thoraces Med 2010; 5: 193-194.

5. World Health Organization. WHO report on the global tobacco epidemic, 2017: monitoring tobacco use and prevention policies. [cited 2017]. Available from: https://apps.who.int/ iris/bitstream/handle/10665/255874/9789241512824-eng.pd f;jsessionid $=7674$ D5E81D1314C9FE0C2393B3844878? sequ ence $=1$
6. Al-Mohrej OA, AlTraif SI, Tamim HM, Fakhoury H. Will any future increase in cigarette price reduce smoking in Saudi Arabia? Ann Thorac Med 2014; 9: 154-157.

7. Almutairi KM. Trends in Current Tobacco Use, Smoking Rates and Quit Attempts among Saudi Population during Periods of 17 Years (1996-2012): Narrative Review Article. Iran J Public Health 2015; 44: 170-175.

8. Hughes N, Arora M, Grills N. Perceptions and impact of plain packaging of tobacco products in low and middle income countries, middle to upper income countries and low-income settings in high-income countries: a systematic review of the literature. BMJ Open 2016; 6: e010391.

9. World Health Organization. Plain packaging of tobacco products: evidence, design and implementation. [cited 2016]. Available from: https://apps.who.int/iris/bitstream/handle/10 665/207478/9789241565226_eng.pdf?sequence $=1$

10. Zacher M, Bayly M, Brennan E, Dono J, Miller C, Durkin $S$, et al. Personal tobacco pack display before and after the introduction of plain packaging with larger pictorial health warnings in Australia: an observational study of outdoor café strips. Addiction 2014; 109: 653-662.

11. Mitchell AD, Studdert DM. Plain packaging of tobacco products in Australia: a novel regulation faces legal challenge. JAMA 2012; 307: 261-262.

12. Moradi-Lakeh M, El Bcheraoui C, Tuffaha M, Daoud F, Al Saeedi M, Basulaiman M, et al. Tobacco consumption in the Kingdom of Saudi Arabia, 2013: findings from a national survey. BMC Public Health 2015; 15: 611.

13. World Health Organization, Centers for Disease Control. Tobacco questions for surveys: a subset of key questions from the Global Adult Tobacco Survey (GATS): global tobacco surveillance system. [cited 2011]. Available from: https://apps. who.int/iris/bitstream/handle/10665/87331/97892415009 51_eng.pdf?sequence $=1$ \&isAllowed $=y$

14. Mallin R. Smoking cessation: integration of behavioral and drug therapies. Am Fam Physician 2002; 65: 1107-1014.

15. Alqarni AM. Saudi smokers' behaviors after a $100 \%$ tax increase. International Journal of Marketing Studies 2019; 11. 150-159.

16. Callison K, Kaestner R. Do higher tobacco taxes reduce adult smoking? New evidence of the effect of recent cigarette tax increases on adult smoking. Economic Inquiry 2014; 52: 155-172.

17. Campaign for Tobacco Free Kids. Raising tobacco taxes a win-win-win. [cited 2018]. Available from: https://www. tobaccofreekids.org/assets/factsheets/0385.pdf

18. Hassounah MM, Al-Zalabani AH, AlAhmari MD, Murriky AA, Makeen AM, Alanazi AMM. Implementation of Cigarette Plain Packaging: Triadic Reactions of Consumers, State Officials, and Tobacco Companies-The Case of Saudi Arabia. Int J Environ Res Public Health 2020; 17: 2668.

19. Mays D, Niaura RS, Evans WD, Hammond D, Luta G, Tercyak KP. Cigarette packaging and health warnings: the impact of plain packaging and message framing on young smokers. Tobacco Control 2015; 24 (e1): e87-e92.

20. Wakefield MA, Hayes L, Durkin S, Borland R. Introduction effects of the Australian plain packaging policy on adult smokers: a cross-sectional study. BMJ Open 2013; 3: e003175. 